\title{
Pentoxifylline As A Radioprotector Against Certain Biochemical And Metal Disorders Of Whole Body Gamma Irradiation In Rats
}

\author{
Esmat A. Shaban and Asrar M. Hawas \\ Department of Drug Radiation Research, National Centre for Radiation Research and \\ Technology, Atomic Energy Authority, Nasr City, Cairo (Egypt)
}

\begin{abstract}
Introduction :- The effect of whole body gamma irradiation at 6.5 Gy dose level on some biochemical indices and metal levels has been investigated in albino rats.

Material And Method:- These included the determination of lipid peroxidation and metallothionein (MT) in liver and kidney. Iron, copper and zinc were measured in liver, kidney spleen and intestine. Also the $\mathrm{P}_{50}$ of survival was determined in rats.

Results:- For the control of these radiation-induced disorders, the radioprotective character of pentoxifylline has been evaluated. Acute $\gamma$-radiation-induced disturbances in trace metals levels in some organs were studied; specially Fe concentrations which were significantly increased $(p \leq 0.05)$ in liver, spleen and intestine. Also $\gamma$-radiation-induced increase in malonaldehyde (MDA) levels as lipid peroxidation indicator and decrease metallothionein (MT)-induction as antioxidant defense induced in the cell. Pre-treatment with pentoxifylline was not effective against the changes produced by acute $\gamma$-radiation on metals studied, lipid peroxidation process and MT-induction. While post treatment showed positive effect on liver iron and metallothionein levels in liver and kidney.
\end{abstract}

Key words: Pentoxifylline, Radioprotector, Gamma irradiation, Metals.

\section{Introduction}

Damage of normal tissue is the most important limiting factor in radiotherapy. It is possible at least theoretically, to eradicate a localized tumor if it is subjected to a large dose of radiation, but, practically; there is always the danger of damaging normal tissues adjacent to the tumor. Recently; attempts have been made to modify this effect by the administration of therapeutic agents after irradiation but before the development of the damage (Rezvani, 2003). One hypothesis states that supplementation with high doses of multiple micronutrients including high doses of antioxidants (vitamins $\mathrm{C}$ and $\mathrm{E}$, and carotenoids) may improve the efficacy of radiation therapy by increasing tumor response and decreasing some of its toxicity on normal cells. Another hypothesis, on the other hand, suggests that antioxidants (dietary or endogenously made) should not be used during radiation therapy, because they would protect cancer cells against radiation damage (Prasad et al, 2002). There are a number of agents, which have been used experimentally, some clinically, to alleviate radiation damage. A number of substances, generally named Biological Response Modifiers (BRMs) with diverse mode of actions have been used in post irradiation modification of normal tissue reactions (Rezvani, 2003). Applications of anticoagulants, heparin (Fleming et al., 1962), and dicumarol (Macht and Perlberg, 1950) as BRMs were the earliest attempts in the treatment of radiation-induced normal tissues lesions (e.g. pneumonitis), however, they were unsuccessful in modifying the development of radiation pneumonitis in the lung. Pentoxifylline has shown significant beneficial effect in the prevention of late radiation effects and recent evidence also suggests that it might be beneficial for the treatment of acute lesions too (Rezvani, 2003). The administration of pentoxifylline as an antiinflammatory may serve as a novel therapeutic adjunct after hemorrhagic chock (Deree et al., 2007).

The present work was planned to evaluate the biochemical changes (lipid peroxidation and metallothionein in liver 
and kidney) as well as the changes in the level of some metals in some organs (liver, kidney spleen and intestine), which might occur in response to whole body gamma irradiation. Moreover, the effect of administration of pentoxifylline, an anticoagulant for five consecutive days before and/or after irradiation on the organs metal levels was studied. The survival rate of animals was also investigated.

\section{Material And Method}

\section{Animals:-}

Seventy-five male albino rats weighing 150-200 g (the Holding Company for Biological Products and Vaccines, Vacsera, Cairo, Egypt) were kept in plastic cages and were allowed free access to tap water and food.

\section{Chemicals:-}

- Nitric acid (65\%) (Scharlau) and hydrogen peroxide (WINLAB) for tissue digestion.

- Ferric chloride (Riedel-deHaën), copper metal (HOPKIN\&WILLIAMS), zinc metal (MERCK) and silver nitrate (PROLABO) for Atomic Absorption Spectrophotometry (AAS) standard preparation.

- Thiobarbituric acid (Sigma), trichloroacetic acid (Aldrich) and n-butanol (Scharlau) for lipid peroxidation determination.

- Silver nitrate, glycine (ADWIC)-NaOH (Riedel-deHaën) buffer, hemolysate for metallothionein determination.

\section{Drugs:-}

Torental (pentoxifylline, Aventis): 50 $\mathrm{mg} / \mathrm{kg}$ body weight given intraperitoneally.

\section{Irradiation:-}

Animals were exposed to an acute whole body $\gamma$-radiation at $6.5 \mathrm{~Gy}$ (dose rate $0.88381 \mathrm{rad} / \mathrm{sec}$.) by using the biological irradiator Gamma cell-40 (caesium-137 source) belonging to National Centre for Radiation Research and Technology (NCRRT) at Nasr City, Cairo.

\section{Equipments:-}

- UNICAM 939 Atomic Absorption Spectrophotometry (AAS).
- Milestone MLS 1200 Mega, High

Performance Microwave Digestor Unit.

- He $\lambda$ ios $\gamma$ UV/VIS Spectrophotometers.

\section{Experimental design:-}

42 rats were divided into 7 groups.

A) Gp1: Normal control (Saline treated group, $n=6$ ):-

Each rat was injected intraperitoneally by $9 \% \mathrm{NaCl}$ for five consecutive days.

\section{B) Irradiated group:-}

12 rats were exposed to gamma irradiation (6.5 Gy), then subdivided into two equal groups, 6 rats each:

Gp2: 6.5 Gy gamma irradiated rats were scarified one day after radiation exposure.

Gp3: 6.5 Gy gamma irradiated rats were scarified three days after radiation exposure.

C) Pentoxifylline treated group, $n=6$ :-

Gp4: Pentoxifylline control treated:

This group of rats was treated intraperitoneally with pentoxifylline (50 $\mathrm{mg} / \mathrm{kg}$ body weight) for five consecutive days.

\section{D) Pretreated irradiated group:}

12 rats received pentoxifylline daily intraperitoneally $(50 \mathrm{mg} / \mathrm{kg}$ body weight) for five consecutive days before irradiation ( $6.5 \mathrm{~Gy})$. The rats were subdivided into two equal groups, 6 rats each:

Gp5: 6 pretreated rats were scarified one day after radiation exposure.

Gp6: 6 pretreated rats were scarified three days after radiation exposure.

\section{E) Post-treated irradiated group:}

Gp7: 6 rats received pentoxifylline daily intraperitoneally $(50 \mathrm{mg} / \mathrm{kg}$ body weight) for five consecutive days after irradiation (6.5Gy), they then were scarified.

- Radioprotective effect of pentoxifylline against mortality:

A group of normal rats $(n=16)$ and a group of rats $(n=16)$ pretreated with pentoxifylline $(50 \mathrm{mg} / \mathrm{kg}$ body weight i.p.) for five consecutive days were subjected to gamma irradiation (6.5 Gy) given as a single dose. The number of rats surviving 28 days after irradiation was counted and the mortality rate was calculated. 


\section{Sample collection:-}

Samples were collected 1 and 3 days after irradiation exposure and 5 days after pentoxifylline treatment. Animals were anesthetized with diethyl ether. Tissues (liver, kidney, spleen and intestine) were separated and washed by deionized water for metal analysis and biochemical determinations (lipid peroxidation and metallothionein in liver and kidney).

\section{Lipid peroxidation determination:-}

Lipid peroxidation levels were ascertained by the formation of malonaldehyde (MDA). Sample preparation for lipid peroxidation was performed as described by Sander et al. (1996). $0.5 \mathrm{ml}$ of homogenate was treated for determination of lipid peroxidation as described by Yoshioka et al. (1979).

\section{Metallothionein determination:-}

Metallothionein levels were determined by Ag-saturation hemolysate method according to Scheuhammer and Cherian (1986) and Bienengräber et al. (1995).

\section{Trace metals analysis:-}

Iron, copper and zinc were measured in the liver, kidney, spleen and intestine. The organs were weighed and put in special vessels with $6 \mathrm{ml}$ nitric acid and $1 \mathrm{ml}$ hydrogen peroxide for the digestion process. Samples were diluted to suitable levels for metals analysis by AAS.

\section{Statistical analysis:-}

Student's t-test was used for statistical analysis of results (Kirkwood, 1988). A p value $\leq 0.05$ was considered significant.

\section{Results}

\section{Survival rate:-}

The results obtained are graphically presented in Fig. (1). Being a sublethal radiation dose $(6.5 \mathrm{~Gy})$, almost all the irradiated control rats have died during the post-exposure period of 18 days. The $\mathrm{P}_{50}$ of survival was 8 days in irradiated rats, and was significantly increased to 20 days in irradiated rats which received pentoxifylline for 5 days prior to gamma irradiation (Fig. 1).
Effect of irradiation and pentoxifylline on metal content compared to normal control (non irradiated control) (Tab.1, Fig.2):-

A) Our results showed significant difference $(p \leq 0.05)$ between both control groups (non irradiated control and pentoxifylline control treated rats); where pentoxifylline caused significant decrease in $\mathrm{Cu}$ liver level. In kidney, there was significant decrease in $\mathrm{Fe}$ and significant increase in $\mathrm{Cu}$ level. In spleen and intestine there were significant decrease in $\mathrm{Fe}$ and $\mathrm{Cu}$ also showed significant decrease in the intestine.

B) One day after irradiation (Tab.1, Fig.2): Liver showed significant increase in $\mathrm{Fe}$ level in irradiated group and significant decrease in $\mathrm{Cu}$ and $\mathrm{Zn}$ levels. Kidney of irradiated rats showed significant decrease in $\mathrm{Fe}$ and $\mathrm{Zn}$ levels and significant increase in $\mathrm{Cu}$ level $(\mathrm{p} \leq 0.05)$. However, the spleen and intestine showed significant increase in $\mathrm{Fe}, \mathrm{Cu}$ and $\mathrm{Zn}$ levels in the $1^{\text {st }}$ day after irradiation $(p \leq 0.05)$.

C) Three days after irradiation (Tab.1, Fig.2): Liver iron concentration was significantly increased while $\mathrm{Cu}$ and $\mathrm{Zn}$ concentrations significantly decreased $(\mathrm{p} \leq 0.05)$. In this group, there was significant increase in kidney $\mathrm{Fe}$ and $\mathrm{Cu}$ and significant decrease in $\mathrm{Zn}$ levels $(p \leq 0.05)$. Spleen metals $(\mathrm{Fe}, \mathrm{Cu}$ and $\mathrm{Zn})$ concentrations showed significant increase in the $3^{\text {rd }}$ day of irradiation. The intestine showed significant increase in Fe.

Effect of irradiation and pentoxifylline on MDA (lipid peroxidation marker) and MT (metallothionein) levels compared to normal control (non irradiated control) (Tab.2, Fig.3):-

There was no significant difference $(p \leq 0.05)$ in MDA levels between both control groups while significant decrease occurred in MT levels. MDA levels showed significant increase in liver at $1^{\text {st }}$ and $3^{\text {rd }}$ days after irradiation. In kidney, there was significant increase in MDA one day after irradiation.

Liver and kidney MT levels showed significant decrease in irradiated and pentoxifylline-treated groups. 
- Effect of pentoxifylline pre-treatment and post-treatment on metal content compared with irradiated group (Tab. 1, Fig. 2):-

A) $1^{\text {st }}$ day pretreated irradiation compared with $1^{\text {st }}$ day irradiation (Tab. 1, Fig. 2):

Liver, spleen and intestine showed significant decrease in $\mathrm{Fe}$ levels and significant increase in $\mathrm{Cu}$ and $\mathrm{Zn}$ levels, except of intestine which had no significant increase in $\mathrm{Cu}$. In kidney, there was significant increase in all metals ( $\mathrm{Fe}, \mathrm{Cu}$ and $\mathrm{Zn}$ ).

B) $3^{\text {rd }}$ day pretreated irradiated group compared with $3^{\text {rd }}$ day irradiated group (Tab. 1, Fig. 2):

In liver, no significant change in $\mathrm{Fe}$ level but there was significant increase in $\mathrm{Cu}$ and $\mathrm{Zn}$ levels. Kidney and spleen exhibited significant increase in all metals $(\mathrm{Fe}, \mathrm{Cu}$ and $\mathrm{Zn}$ ) while intestine showed significant decrease in all metals studied ( $\mathrm{Fe}, \mathrm{Cu}$ and $\mathrm{Zn}$ ).
C) Post-treated irradiated group compared with $1^{\text {st }}$ day irradiated group (Tab. 1, Fig. 2):

There was significant decrease in all metals $(\mathrm{Fe}, \mathrm{Cu}$ and $\mathrm{Zn}$ ) in liver, kidney and intestine with except of liver $\mathrm{Cu}$ and kidney Fe which showed no significant effect. The spleen showed significant increase in $\mathrm{Fe}$ and $\mathrm{Cu}$ and no significant effect in $\mathrm{Zn}$.

- Effect of pentoxifylline pre-treated and post-treated groups on MDA and MT levels compared with irradiated group (Tab.2, Fig.3):-

After 1 day of irradiation, there was non significant effect on MDA in liver and kidney but there was significant decrease in MT levels. $3^{\text {rd }}$ day of irradiation showed significant increase in MDA levels in both organs. In liver, there was significant increase in MT level and significant decrease in kidney MT level. Post-treated irradiated group showed significant decrease in kidney MDA level and significant increase in MT levels in liver and kidney. 
Table (1): Concentration of metals $(\mathrm{Fe}, \mathrm{Cu}$ and $\mathrm{Zn})(\mu \mathrm{g} / \mathrm{g}$ wet weight , mean $\pm \mathrm{SE})$ in liver, kidney, spleen and intestine in male rats $(n=6)$ exposed to $\gamma$-radiation $(6.5 \mathrm{~Gy})$ and/or treated with pentoxifylline $(50 \mathrm{mg} / \mathrm{kg}$ body weight for five consecutive days) prior and post irradiation exposure (mean $\pm \mathrm{SE}$ ).

\begin{tabular}{|c|c|c|c|c|c|c|c|}
\hline \multirow{2}{*}{$\begin{array}{l}\text { Groups } \\
\text { Organs }\end{array}$} & \multirow{2}{*}{$\begin{array}{c}\text { Non } \\
\text { irradiated } \\
\text { control }\end{array}$} & \multicolumn{2}{|c|}{ Irradiation only } & \multirow{2}{*}{$\begin{array}{l}\text { Pentoxifylline } \\
\text { control treated }\end{array}$} & \multicolumn{2}{|c|}{ Pretreated irradiation } & \multirow{2}{*}{$\begin{array}{l}\text { Post-treated } \\
\text { irradiation }\end{array}$} \\
\hline & & \multicolumn{2}{|c|}{$1^{\text {st day }} \quad 3^{\text {rd day }}$} & & \multicolumn{2}{|c|}{$1^{\text {st }}$ day $\quad 3^{\text {rd day }}$} & \\
\hline Liver & $183.7 \pm 3.519$ & $228.3 \pm 9.924^{*}$ & $230.1 \pm 6.087^{*}$ & & $144.5 \pm 3.890^{* * *}$ & $232.0 \pm 3.835$ & \\
\hline $\mathbf{C u}$ & $3.150 \pm 0.111$ & $2.382 \pm 0.077^{*}$ & & $039 *$ & & & \\
\hline $\mathbf{Z n}$ & $33.18 \pm 1.215$ & $24.99 \pm 0.821^{*}$ & $26.72 \pm 0.978^{*}$ & $30.92 \pm 1.445$ & $29.58 \pm 0.774 * *$ & $32.70 \pm 0.817 * *$ & $22.56 \pm 0.728 * *$ \\
\hline Kidney & $121.9 \pm 2.425$ & $110.0 \pm 1.642 *$ & $131.0 \pm 3.017^{*}$ & $110.4 \pm 1.942 *$ & $162.8 \pm 3.923$ & $151.8 \pm 3.086^{\circ}$ & \\
\hline $\mathbf{C u}$ & $3.645 \pm 0.081$ & $3.981 \pm 0.077 *$ & $4.087 \pm 0.134 *$ & $111^{*}$ & & & \\
\hline $\mathbf{Z n}$ & $34.11 \pm 1.094$ & $29.28 \pm 0.904 *$ & $29.61 \pm 0.986^{*}$ & $32.04 \pm 0.849$ & $39.44 \pm 0.370^{* *}$ & $38.48 \pm 1.358 * *$ & $26.70 \pm 0.944 * *$ \\
\hline Spleen & $1003 \pm 39.02$ & $1385 \pm 64.23^{*}$ & $1300 \pm 29.73 *$ & $784.9 \pm 36.91 *$ & $1157 \pm 51.45 * *$ & $1861 \pm 99.54 * *$ & $2091 \pm 105.4 * *$ \\
\hline $\mathbf{C u}$ & $1.280 \pm 0.060$ & $1.444 \pm 0.035^{*}$ & $1.843 \pm 0.057 *$ & $1.289 \pm 0.060$ & $2.806 \pm 0.027 * *$ & $2.779 \pm 0.123^{* *}$ & $1.990 \pm 0.053 * *$ \\
\hline $\mathbf{Z n}$ & $30.55 \pm 1.171$ & $38.07 \pm 1.272^{*}$ & $40.22 \pm 0.670^{*}$ & $33.29 \pm 1.146$ & $61.54 \pm 1.344 * *$ & $71.42 \pm 2.216^{* *}$ & $40.95 \pm 1.626$ \\
\hline Intestine $\mathrm{Fe}$ & $31.21 \pm 1.048$ & $42.56 \pm 1.714^{*}$ & $42.10 \pm 1.544^{*}$ & $25.68 \pm 1.380^{*}$ & $39.83 \pm 1.373^{* *}$ & $35.14 \pm 0.813^{* *}$ & $29.27 \pm 0.993^{* *}$ \\
\hline $\mathbf{C u}$ & $1.451 \pm 0.033$ & $1.603 \pm 0.049 *$ & $1.467 \pm 0.064$ & $1.325 \pm 0.040 *$ & $1.668 \pm 0.066$ & $1.305 \pm 0.028 * *$ & $1.175 \pm 0.031 * *$ \\
\hline $\mathbf{Z n}$ & $32.65 \pm 1.356$ & $38.81 \pm 0.899^{*}$ & $35.62 \pm 0.985$ & $29.18 \pm 1.402$ & $42.53 \pm 0.693 * *$ & $32.86 \pm 0.922 * *$ & $29.14 \pm 1.200^{* *}$ \\
\hline
\end{tabular}

* Significantly different from mon irradiated control at $\mathrm{p} \leq 0.05$.

** Significantly different from irradiated group at $\mathrm{p} \leq 0.05$.

Table (2): Concentration of MDA ( $\mathrm{nmol} / \mathrm{g}$ wet weight) and MT ( $\mu \mathrm{g} / \mathrm{g}$ wet weight) (mean \pm $\mathrm{SE})$ in liver and kidney in male rats $(\mathrm{n}=6)$ exposed to $\gamma$ - radiation (6.5 Gy) and/or treated with pentoxifylline $(50 \mathrm{mg} / \mathrm{kg}$ body weight for five consecutive days) prior and post irradiation exposure (mean $\pm \mathrm{SE}$ ).

\begin{tabular}{|c|c|c|c|c|c|c|c|}
\hline \multirow{2}{*}{$\begin{array}{l}\text { Groups } \\
\text { Organs }\end{array}$} & \multirow{2}{*}{$\begin{array}{c}\text { Non } \\
\text { irradiated } \\
\text { control }\end{array}$} & \multicolumn{2}{|c|}{ Irradiation only } & \multirow{2}{*}{$\begin{array}{c}\text { Pentoxifylline } \\
\text { Control } \\
\text { treated }\end{array}$} & \multicolumn{2}{|c|}{ Pretreated irradiation } & \multirow{2}{*}{$\begin{array}{l}\text { Post-treated } \\
\text { irradiation }\end{array}$} \\
\hline & & $1^{\text {st }}$ day & $3^{\text {rd day }}$ & & $1^{\text {st }}$ day & $3^{\text {rd day }}$ & \\
\hline $\begin{array}{cc}\text { Liver } & \begin{array}{c}\text { MDA } \\
\text { MT }\end{array}\end{array}$ & $\begin{array}{l}82.36 \pm 2.522 \\
995.2 \pm 37.53\end{array}$ & $\begin{array}{l}105.9 \pm 1.222^{*} \\
727.2 \pm 34.08^{*}\end{array}$ & $\begin{array}{l}97.19 \pm 2.135^{*} \\
283.9 \pm 7.267^{*}\end{array}$ & $\begin{array}{c}86.53 \pm 2.648 \\
614.4 \pm 23.38^{*}\end{array}$ & $\begin{array}{c}107.3 \pm 1.475 \\
422.7 \pm 10.86 * *\end{array}$ & $\begin{array}{l}176.1 \pm 2.206^{* *} \\
417.2 \pm 7.669^{* *}\end{array}$ & $\begin{array}{c}110.6 \pm 5.377 \\
823.0 \pm 31.68 * *\end{array}$ \\
\hline 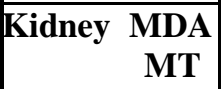 & $\begin{array}{l}121.1 \pm 1.316 \\
988.3 \pm 35.12\end{array}$ & $\begin{array}{l}133.8 \pm 1.654^{*} \\
675.6 \pm 20.76^{*}\end{array}$ & $\begin{array}{c}123.4 \pm 1.603 \\
596.7 \pm 16.80^{*}\end{array}$ & $\begin{array}{c}119.2 \pm 4.204 \\
699.5 \pm 12.57 *\end{array}$ & $\begin{array}{c}136.4 \pm 2.722 \\
604.0 \pm 15.38 * *\end{array}$ & $\begin{array}{l}208.6 \pm 4.343^{* * *} \\
553.9 \pm 14.74^{* *}\end{array}$ & $\begin{array}{l}127.8 \pm 2.360^{* * *} \\
961.8 \pm 45.14 * *\end{array}$ \\
\hline
\end{tabular}

* Significantly different from mon irradiated control at $p \leq 0.05$.

** Significantly different from irradiated group at $\mathrm{p} \leq 0.05$.

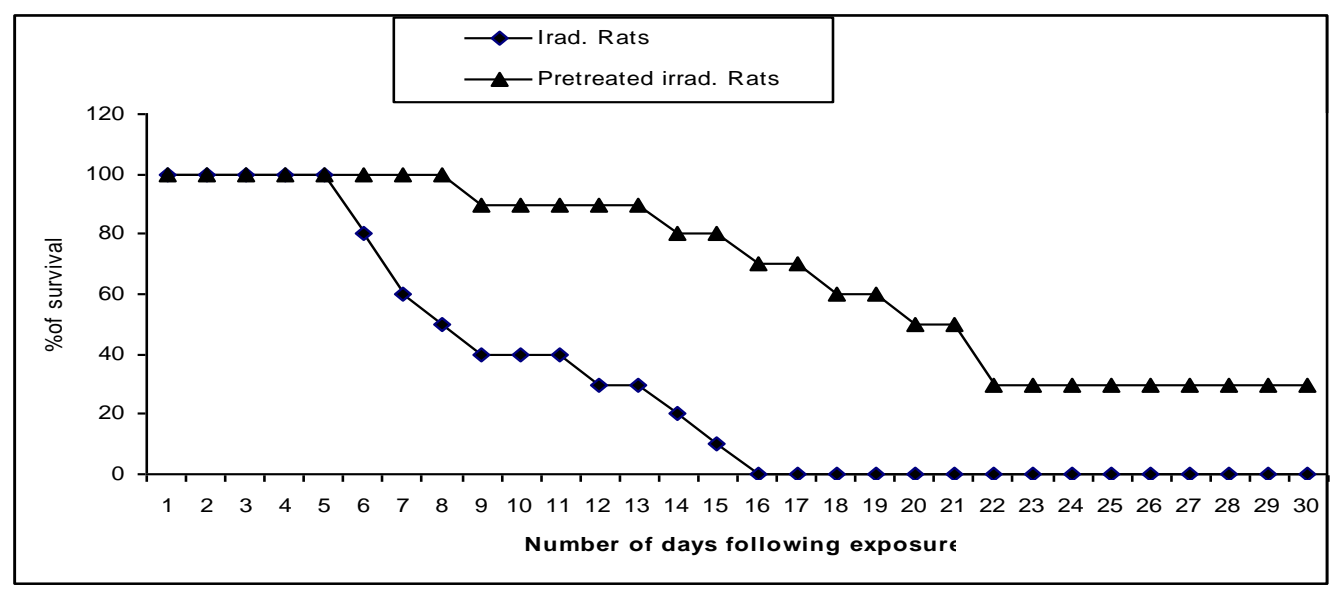

Fig. (1): Survival rate of irradiated rats $\left(P_{50}=8\right)$ compared to pretreated irradiated rats $\left(\mathbf{P}_{50}=\mathbf{2 0}\right)$ 

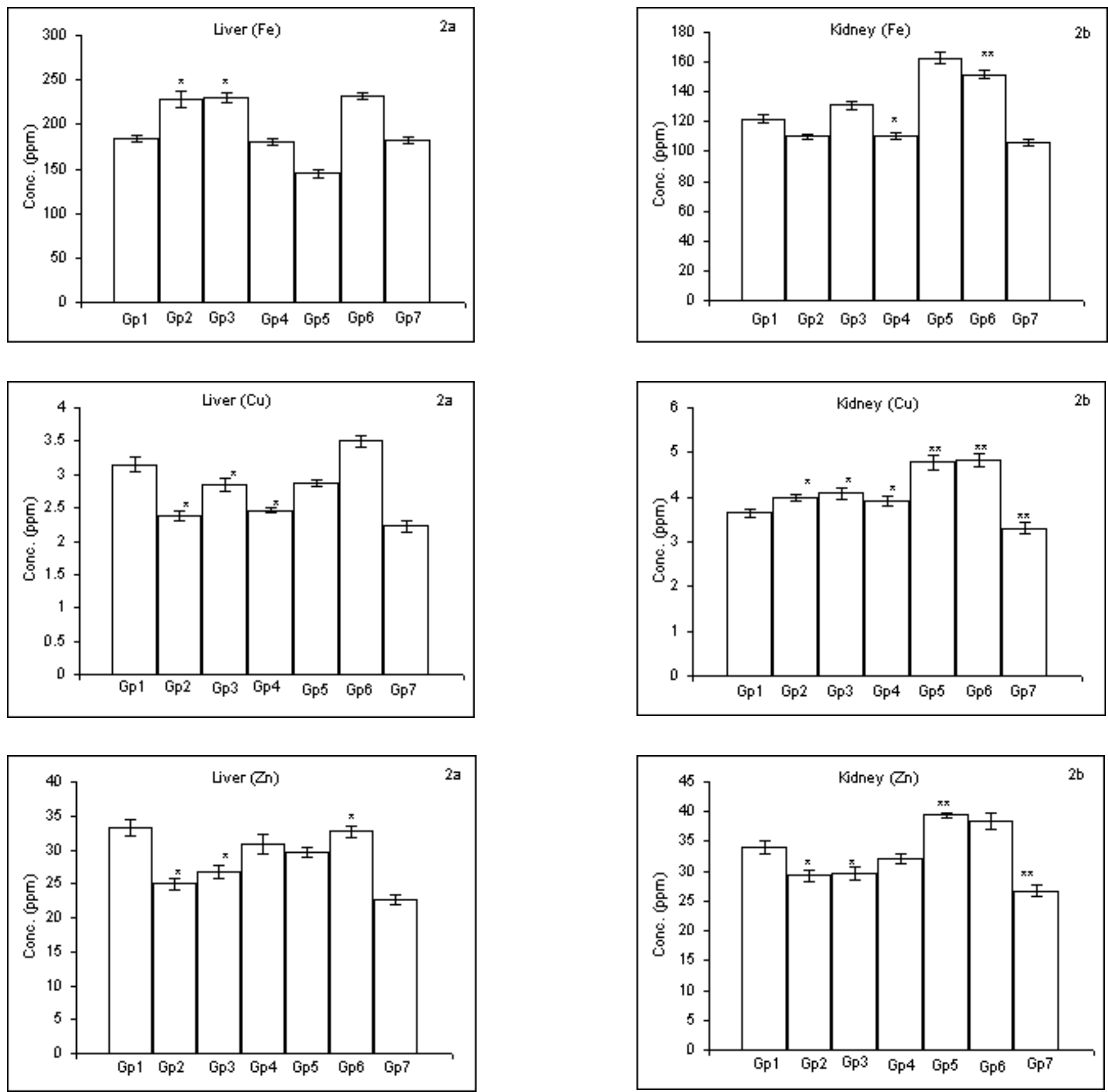

Fig. (2a): Concentration of metals (ug/g wet weight, mean $\pm \mathrm{SE})$ in rats $(\mathrm{n}=6)$ liver exposed to $\gamma$-radiation $(6.5 \mathrm{~Gy})$ and/or pentoxifylline $(50 \mathrm{mg} / \mathrm{kg}$ body weight for five consecutive days).

Fig. (2b): Concentration of metals (ug/g wet weight, mean $\pm \mathrm{SE}$ ) in rats $(\mathrm{n}=6)$ kidney exposed to $\gamma$-radiation (6.5 Gy) and/or pentoxifylline $(50 \mathrm{mg} / \mathrm{kg}$ body weight for five consecutive days).

* Significant difference at $\mathrm{p} \leq 0.05$ as compared to normal control(Gp 1).

** Significant difference at $\mathrm{p} \leq 0.05$ as compared to iradiated control.

N.B.: $1^{\text {st }}$ day pre-treated irradiated group (Gp 5) compared to $1^{\text {st }}$ day irradiated group (Gp 2).

$3^{\text {rd }}$ day pre-treated irradiated group (Gp 6) compared to $3^{\text {rd }}$ day irradiated group (Gp 3).

Post-treated irradiated group (Gp 7) compared to $1^{\text {st }}$ day irradiated group (Gp 2). 

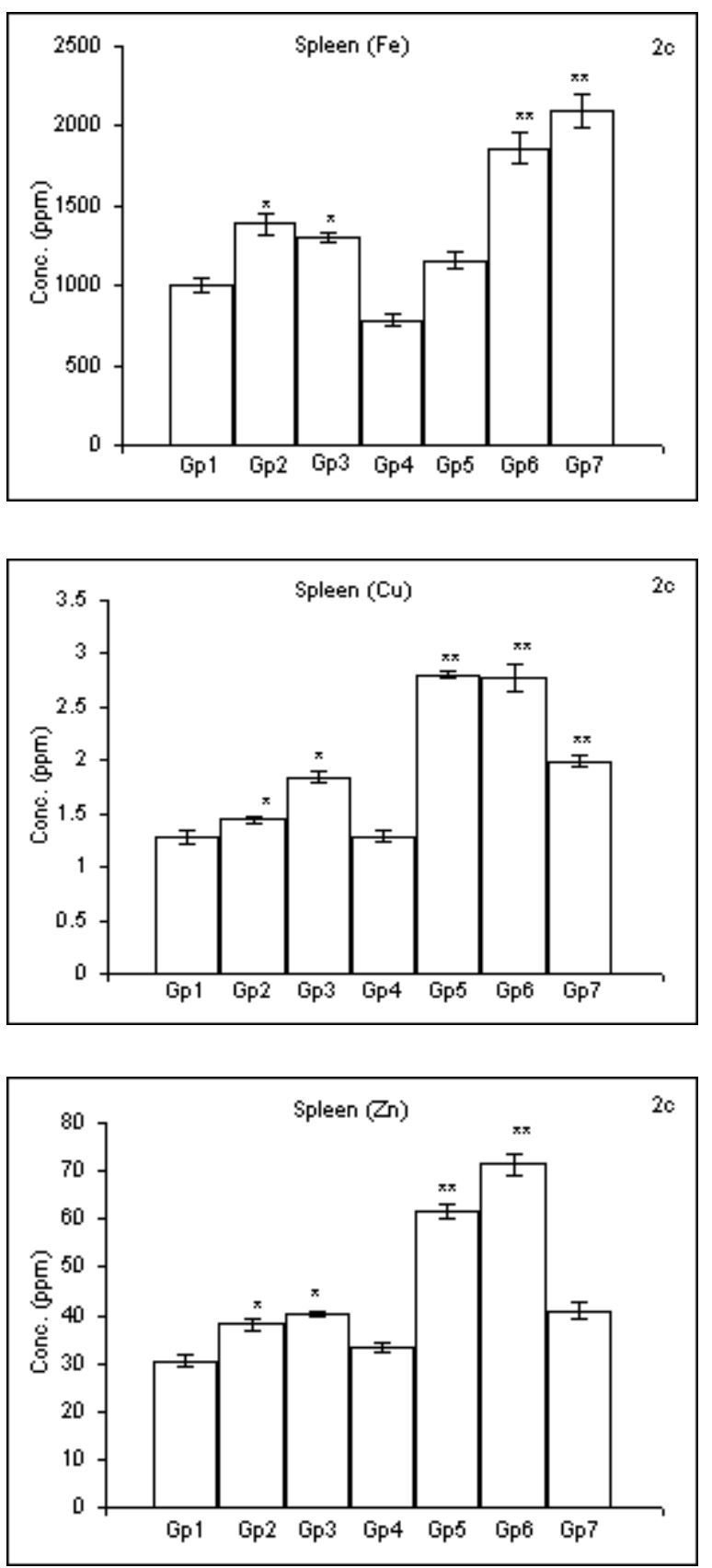

Fig. (2c): Concentration of metals (ug/g wet weight, mean $\pm \mathrm{SE})$ in rats $(\mathrm{n}=6)$ spleen exposed to $\gamma$-radiation (6.5 Gy) and/or pentoxifylline $(50 \mathrm{mg} / \mathrm{kg}$ body weight for five consecutive days).
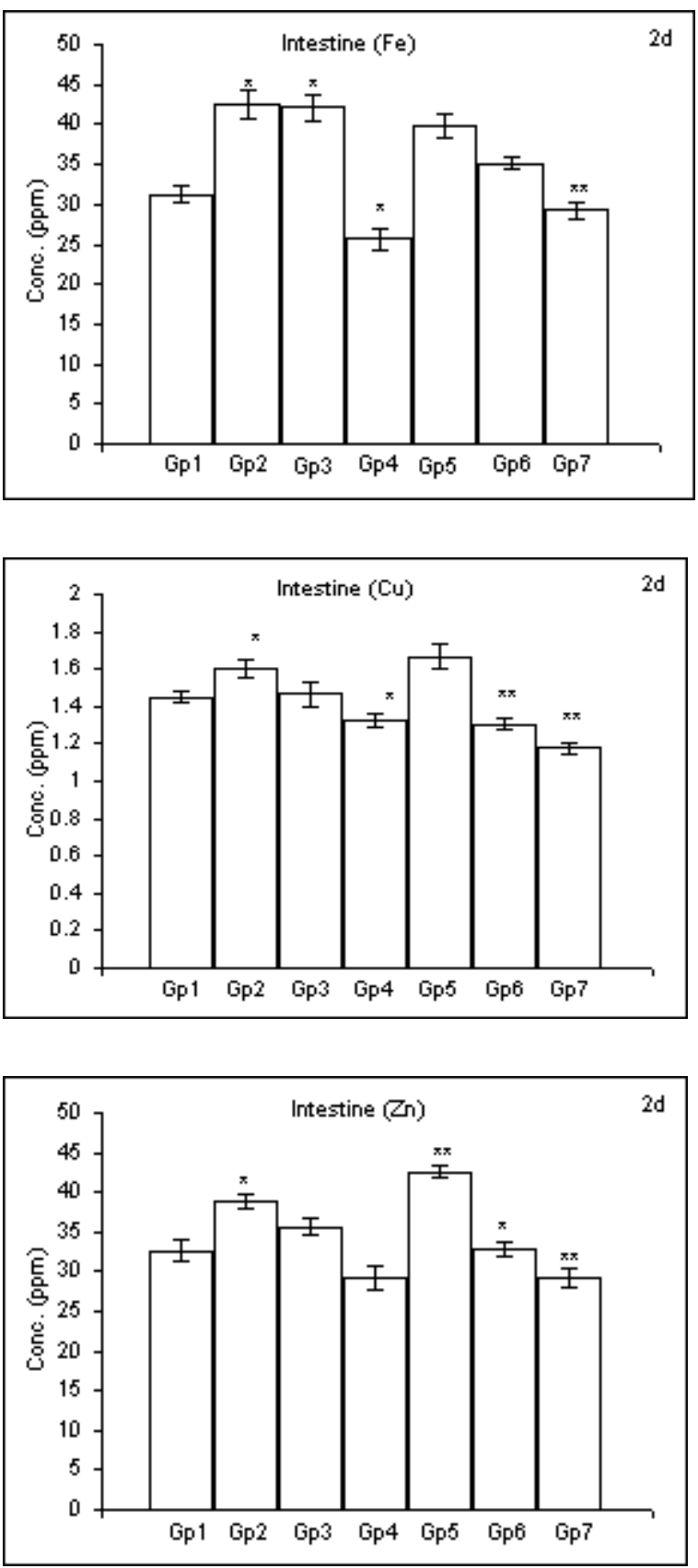

Fig. (2d): Concentration of metals (ug/g wet weight, mean \pm SE) in rats $(n=6)$ intestine exposed to $\gamma$-radiation (6.5 Gy) and/or pentoxifylline $(50 \mathrm{mg} / \mathrm{kg}$ body weight for five consecutive days).

* Significance difference at $p \leq 0.05$ as compared to normal control(Gp 1).

** Significance difference at $p \leq 0.05$ as compared to irradiated control.

N.B.: $1^{\text {st }}$ day pre-treated irradiated group (Gp 5) compared to $1^{\text {st }}$ day irradiated group (Gp 2).

$3^{\text {rd }}$ day pre-treated irradiated group (Gp 6) compared to $3^{\text {rd }}$ day irradiated group (Gp 3).

Post-treated irradiated group (Gp 7) compared to $1^{\text {st }}$ day irradiated group (Gp 2). 

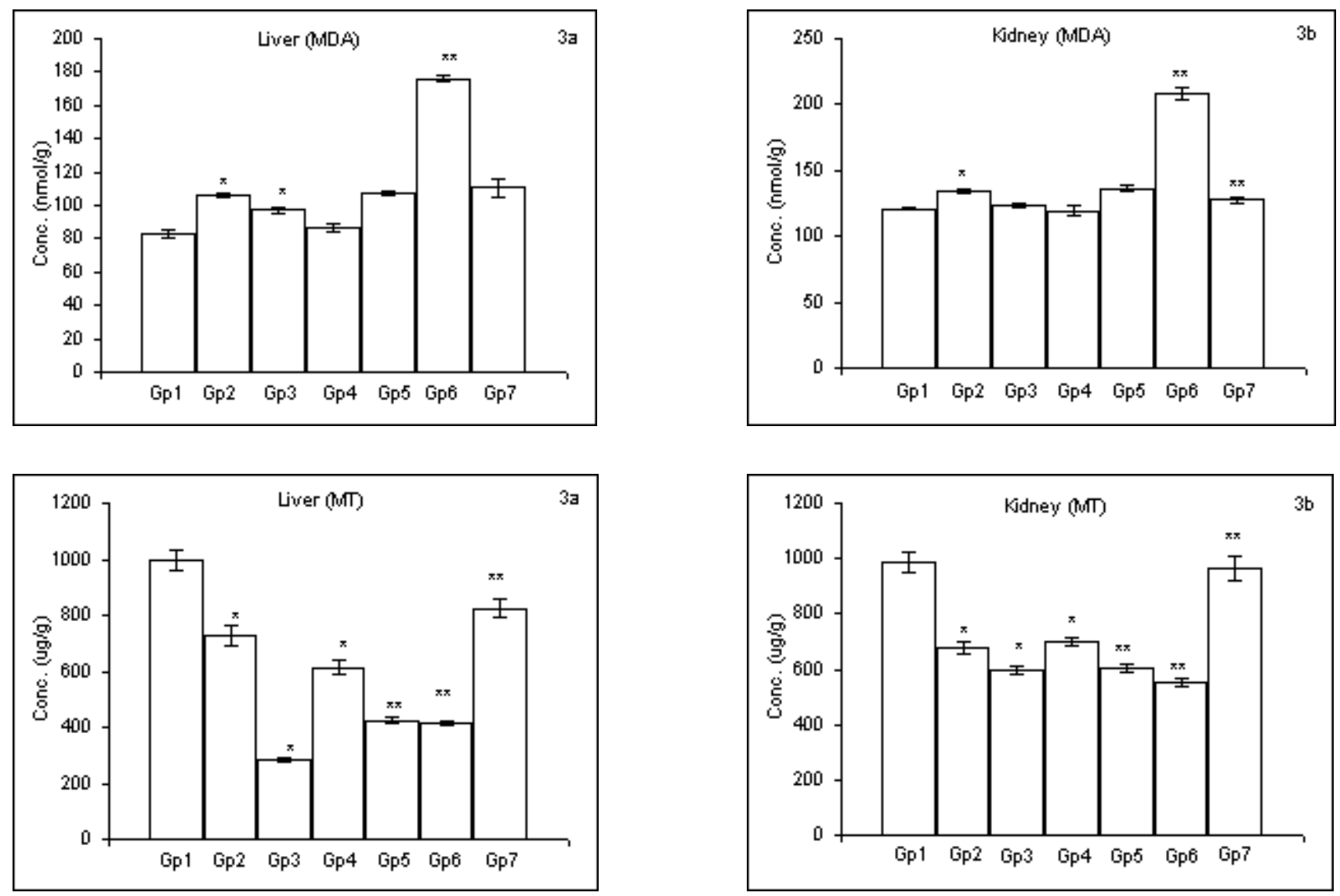

Fig. (3): MDA and MT levels (mean \pm SE) in rats $(n=6)$ liver and kidney exposed to $\gamma$-radiation (6.5 Gy) and/or pentoxifylline (50 $\mathrm{mg} / \mathrm{kg}$ body weight for five consecutive days).

* Significance difference at $\mathrm{p} \leq 0.05$ as compared to normal control(Gp 1).

** Significance difference at $\mathrm{p} \leq 0.05$ as compared to irradiated control.

N.B.: $1^{\text {st }}$ day pre-treated irradiated group (Gp 5) compared to $1^{\text {st }}$ day irradiated group (Gp 2).

$3^{\text {rd }}$ day pre-treated irradiated group (Gp 6) compared to $3^{\text {rd }}$ day irradiated group (Gp 3).

Post-treated irradiated group (Gp 7) compared to $1^{\text {st }}$ day irradiated group (Gp 2).

\section{Discussion}

In the present work, we investigated the effect of $\gamma$-radiation and/or pentoxifylline on certain trace metals concentration ( $\mathrm{Fe}, \mathrm{Cu}$ and $\mathrm{Zn}$ ), these metalloelements are required by all cells for normal metabolic processes (Tipton and Cook, 1963). Trace elements play a very important role in many biological activities; their imbalance may be a contributor to, or a result of organ dysfunction (Elnimr and Abdel-Rahim, 1998). It is recognized that loss of enzymes activity dependent on essential metalloelements may at least partially account for lethality of ionizing radiation and that $\mathrm{Fe}-, \mathrm{Cu}-, \mathrm{Mn}-$ and $\mathrm{Zn}$ dependent enzymes have roles in protecting against accumulation of $\mathrm{O}_{2}$ as well as in facilitating repair (Gelman et al, 1978).

The liver histopathological changes seen post-irradiation, include occlusion of the small hepatic veins leading to sinus congestion, hyperemia and hemorrhage (Edward, 1990) which may explain the $\mathrm{Fe}$ increasing in liver at $1^{\text {st }}$ and $3^{\text {rd }}$ days after irradiation (Tab.1, Fig.2a) and the excess of iron presented to the kidney (at $3^{\text {rd }}$ day after irradiation, Tab.1, Fig.2b) for excretion and conversion to ferritin (Hampton and Mayerson, 1950).

Irradiated group showed significant increase in spleen iron levels (Tab.1, Fig.2c) one and three days after irradiation 
compared with control Kotb et al. (1990) reported that accumulation of iron in the spleen may result from disturbance in the biological function of red blood cells, including possible intravascular hemolysis and subsequent storage of iron in the spleen. At the $1^{\text {st }}$ day in pretreated irradiated group, $\mathrm{Fe}$ levels decreased in liver, spleen and intestine (Tab.1, Fig.2a,c,d) compared with irradiated group and in post-treated irradiated group, $\mathrm{Fe}$ levels decreased in liver and intestine (Tab.1, Fig.2a,d). It is known that the basic action of pentoxifylline is increasing of red blood cells flexibility, reduction of blood viscosity and decrease potential of platelet aggregation (Okunieff et al, 2004; Windmeier and Gressner, 1997) which may ameliorate the deleterious effect of radiation. After the $3^{\text {rd }}$ day of irradiation, the kidney exhibited significant increase in $\mathrm{Fe}$ and $\mathrm{Cu}$ levels (Tab.1, Fig.2b). Cengiz et al. (2003) concluded that a sublethal dose of total body irradiation causes deposition of $\mathrm{Cu}$ and $\mathrm{Fe}$ within the kidney 8 weeks after irradiation. Deposition of these elements may have some additional role of the toxicity caused by direct radiation on the kidney. Yarmonenko (1988) mentioned that the effect of radiation on gastrointestinal tract includes baring of the villi, infection, damage to the blood vessels and disturbance of the balance of liquid and electrolytes. Gregus and Klaassen (1986) reported that fecal excretion of metals may originate from hepatobiliary transport. There was significant increase in the intestine $\mathrm{Zn}$ level at $1^{\text {st }}$ day after irradiation compared with control and at the $1^{\text {st }}$ day of pretreated irradiated group compared with $1^{\text {st }}$ day of irradiated group (Tab.1, Fig.2d). Solomons and Cousins (1984) noted that substantial amount of zinc is excreted by the pancreas and secreted by the small intestine.

The increasing of the oxidative stress via radiation exposure effects inhibit the antioxidant defense system (Carrier et al, 2002), and induce oxidative modifications of the membranes, thus, increase fragility of red blood cells ( wagner et al, 1988; Stern, 1986). Increasing of MDA (as lipid peroxidation indicator) levels in liver and kidney (Tab.2, Fig.3a,b) refer to the damage effect of radiation as free radical inducing factor (Sun et al, 1995). The preand post-treatment by pentoxifylline (50 $\mathrm{mg} / \mathrm{kg}$ body weight for five consecutive days) as radioprotector drug for this acute dose of radiation $(6.5 \mathrm{~Gy})$ cannot prevent the damage effect of radiation. Metallothionein levels in liver and kidney (Tab.2, Fig.3a,b) was affected by radiation, where significant decrease occurred in all groups with exception of post-treated group with pentoxifylline while metallothionein level started to elevate but not restored completely to the control levels especially in liver.

It is known that pentoxifylline has a radio-protective effect which can prevent or ameliorate late radiation injury in animals and humans (Stelzer et al, 1994). The most important pentoxifylline mechanism for altering radiation damage may be its ability to increase locoregional blood flow. Pentoxifylline improves blood flow by a multi-tiered process. Firstly it inhibits cAMP phosphodiesterase and thereby increases cAMP (Windmeier and Gressner, 1997) and ATP in RBCs, improving their deformability. Pentoxifylline also can promote streamlined blood flow by inhibiting intercellular adhesion molecule (ICAM) expression, minimizing leukocyte adherence to endothelial cells, and increasing prostacycline production, thus, inhibiting platelet aggregation. By increasing prostacycline levels and decreasing thromboxane effect, pentoxifylline dilates capillaries. Finally, it decreases plasma fibrinogen concentrations and increases fibrinolytic activity. Each of these effects alone could improve vascular blood flow. In concert, these effects decrease both whole blood viscosity, and systemic vascular resistance. The alleviation of tissue hypoxia in turn may reduce angiogenic stimuli and thus could account for the reduced Fibroplast Growth Factor 2 levels (FGF2) (Okunieff et al, 2004). Also Maiti et al. (2007) study revealed improvement in inflammatory markers, oxidative stress and platelet aggregation by pentoxifylline.

In the present study, pre-treatment by pentoxifylline $(50 \mathrm{mg} / \mathrm{kg}$ body weight for five consecutive days) was not effective against the damaging effects of acute radiation (dose $6.5 \mathrm{~Gy}$ ) on metals $(\mathrm{Fe}, \mathrm{Cu}$ and $\mathrm{Zn}$ ) in liver, kidney, spleen and 
intestine, also on lipid peroxidation process and metallothionein induction in liver and kidney. While post treatment showed positive effect on liver iron and metallothionein levels in liver and kidney.

According to Misirliogu et al. (2007), the combined use of pentoxifylline and vitamin $\mathrm{E}$ is reported to reduce radiationinduced toxicity on normal tissues at molecular levels.

Increasing experimental and clinical evidence suggests the efficacy of pentoxifylline in the treatment of radiation injury; particularly late effect. Thus pentoxifylline, particularly combined with $\alpha$-tocopherol (vitamin E) may act as an effective Biological Response Modifier (BRM). Also long term administration of pentoxifylline in animal prior to radiation exposure may prevent the deleterious damage effect of acute $\gamma$-radiation exposure.

\section{References}

1. Bienengräber M, Forderkunz S, Klein D and Summer KH (1995): Determination of $\mathrm{Cu}$-containing metallothionein: comparison by Ag saturation assay, thiomolybdate assay and enzyme-linked immuonosorbent assay. Anal. Biochem. 228: 69-73.

2. Carrier J, Aghdassi E, Cullen $\mathbf{J}$ and Allard JP (2002): Ion supplementation increases disease activity and vitamin $\mathrm{E}$ ameliorates the effect in rats with dextran sulfate sodium-induced colitis. J. Nutr. 132: 3146-3150.

3. Cengiz M, Gurkaynak M, Vural H, Aksoy N, Cengiz B, Yildiz F and Atahan IL (2003): Tissue trace element change after total body irradiation. Nephron Exp. Nephrol. 94(1): e12-e16.

4. Deree J, Martins J, de Campos T, Putman JG, Loomis WH, Wolf $P$ and Coimbra R (2007): Pentoxifylline attenuates lung injury and modulates transcription factor activity in hemorrhagic shock. J. Surg. Res. 143(1): 99-108.

5. Edward LA (1990): Late effects of radiation on normal tissues, non stochastic effects. In: Radiation biophysics (PrenticHall, Inc. ed.) Pp. 227-254.

6. Elnimr T and Abdel-Rahim SM (1998): Effect of $\gamma$-radiation on some elements in certain organs of albino rats. Boil. Trace Elem. Res. 62: 25-30.

7. Fleming WH, Szakacz JE, King ER, Martin ML and Roche JJ (1962): The effect of gamma radiationon the fibrinolytic system of dog lung and its modification by certain drugs: relationship to radiationpnuemonitis and hyaline membrane formation in lung. J. Nucl. Medicine 3: 341-351.

8. Gelman BB, Michealson IA and Bus JS (1978): The effect of lead on oxidative hemolysis and erythrocyte defense mechanisms in the rat. Toxicol. Appl. Pharmacol. 45: 119-129.

9. Gregus $Z$ and Klaassen CD (1986): Deposition of metals in rats: a comparative study of fecal, urinary and biliary excretion ad tissue distribution of eighteen metals. Toxicol. Appl. Pharmacol. 85: 24-38.

10. Hampton JK Jr and Mayerso HS (1950): Hemoglobin iron as a stimulus for the production of firritin by the kidney. Am. J. Physiol. 160(1): 1-8.

11. Kirkwood BR (1988): Comparison of two means. In: Essentials of medical statistics. (B.R. Kirkwood, ed.) Pp. 41-45. Blackwell Scientific Publications.

12. Kotb MA, El-Khatib AM, Morsey AA, Ramadan MIA and EI-Bassiouni EA (1990): Changes in mineral elements in some tissues of mice following neutron irradiation. Isotopenpraxis. 26(7): 297-300.

13. Macht SH and Perlberg H (1950): Use of anticoagulant (Dicumarol) in preventing post-irradiation tissue changes in the human lung. Am. J. Roentgenol. 63: 335-341.

14. Maiti R, Agrawal NK, Dash D and Pandey BL (2007): Effect of pentoxifylline on inflammatory burden, oxidative stress and platelet aggregability in hypertensive type 2 diabetes mellitus patients. Vascul. Pharmacol. 47(2-3): 118-124.

15. Misirliogu GH, Demirkasimoglu T, Kucukplakci B, Sanri E and Altundag K (2007): Pentoxifylline and alpha-tocopherol in prevention of radiation induced lung toxicity in patients with lung cancer. Med. Oncol. 24(3): 308-311.

16. Okunieff P, Augustine E, Hicks J E, Cornelison TL, Altemus RM, Naydich BG, Ding I, Huser AK, Abraham EA, Smith JJ, Goleman N and Gerber LH (2004): Pentoxifylline in the treatment of radiation-induced fibrosis. J. Clin. Oncol. 22(11): 2207-2213.

17. Prasad KN, Cole WC, Kumar B and Che Prasad K (2002). Pros and Cons of 
antioxidant use during radiation therapy. Cancer Treatment Rev. 28: 79-91.

18. Rezvani M (2003): Treatment of radiationinduced normal tissue lesions. Iran. J. Radiat. Res. 1(2): 63-78.

19. Sander S, Chakraborty A and Chatterjee M (1996): Comparative effectiveness of vitamin $\mathrm{D}_{3}$ and dietary vitamin $\mathrm{E}$ on peroxidation of lipid and enzymes of the hepatic antioxidant system in SpragueDawley rats. Int. J. Vit. Nutr. Res. 66: 3945.

20. Scheuhammer AM and Cherian MG (1986): Quantification of metallothioneins by a silver-saturation method. Toxicol. Appl. Pharmacol. 82: 417-425.

21. Solomons NW and Cousins RJ (1984): Zinc. In: Absorption and malabsorption of mineral nutrients. (N.W. Solomons and I.H. Resenberg, eds.) Pp. 125-197. Liss, New York.

22. Stelzer KJ, Koh WJ, Kurtz H, Greer BE and Griffin TW (1994): Caffeine consumption is associated with decreased severe late toxicity after radiation to the pelvis. Int. J. Radiat. Oncol. Boil. Phys. 30(2): 411-417.

23. Stern A (1986): Red cell oxidative damage. In: Oxidative stress. (H. Sies, ed.) Pp. 331-349. Academic Press, London, UK.
24. Sun E, Xu H, Liu Q, Zhou J, Zuo P and Wang J (1995): Effect of selenium in recovery of immunity damage by $\mathrm{H}_{2} \mathrm{O}_{2}$ and ${ }^{60}$ Co radiation. Boil. Trace Elem. Res. 48: 239-250.

25. Tipton IH and Cook MJ (1963): Trace elements in human tissue. II. Adult subjects from the United States. Health Phys. 1: 103-145.

26. Wagner GM, Lubin BH and Chiu D.T.Y. (1988): Oxidative damage to red blood cells. In: Cellular antioxidant defense mechanisms. (C.K. Chow, ed.) Vol. 1, Pp. 185-195. CRC Press Inc., Boca Raton, FL.

27. Windmeier C and Gressner AM (1997): Pharmacological aspects of pentoxifylline with emphasis on its inhibitory action of hepatic fibrogenesis. Gen. Pharmacol. 29(2): 181-196.

28. Yarmonenko SP (1988): Radiobiology of an organism. In: Radiobiology of humans and animals. (G. Leib, ed.) Pp. 123-153. Mir Publishers, Moscow.

29. Yoshioka T, Kawada K, Shimada T and Mori M (1979): Lipid peroxidation in maternal and cord blood and protective mechanism against activated-oxygen toxicity in the blood. Am. J. Obstet. Gynecol. 135: 372-376. 


\section{الدور الوقائى لاواء البنتوكسيفيلين ضد الإختلال الكيموحيوية والتفير فى المئ

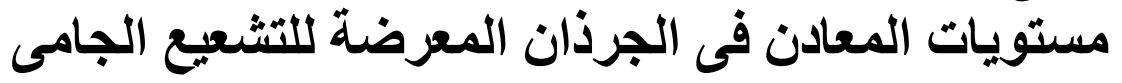

\author{
عصمت عبد السلام شعبان، أسرار محمد مراد حواس الاس
} المركز القومى لبحوث وتكنولوجيا الإشعاع - هيئة الطاقة الأرية مئل}

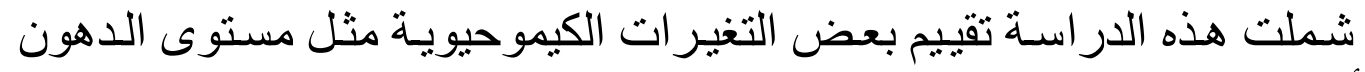

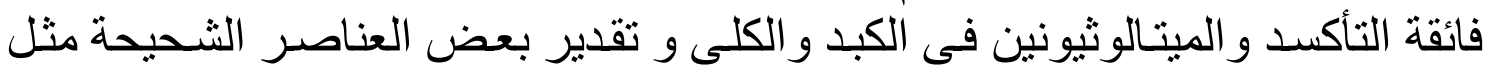

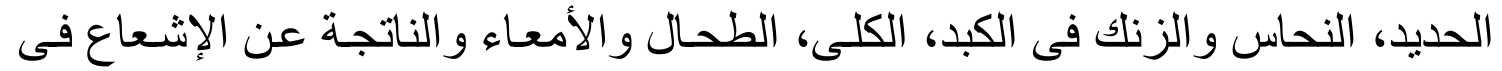

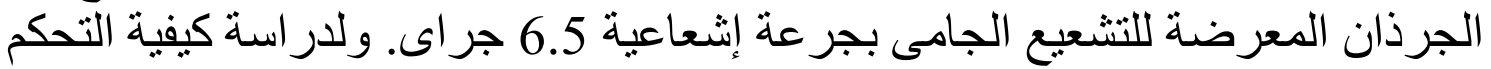

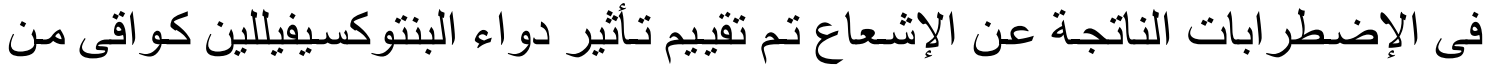

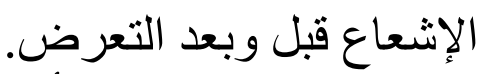

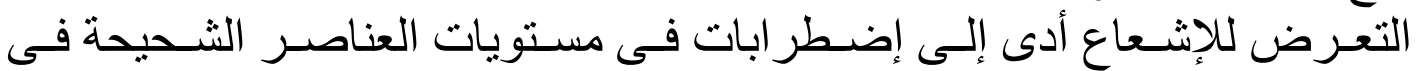

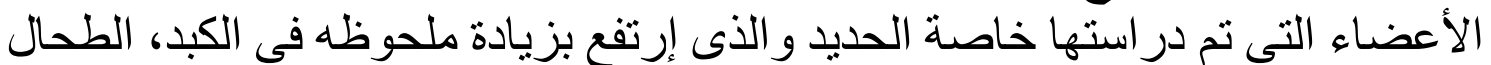

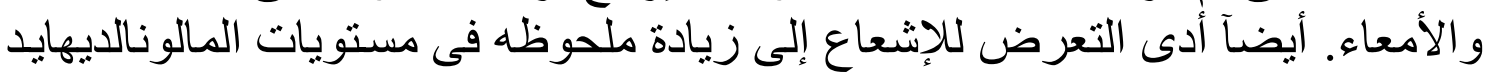

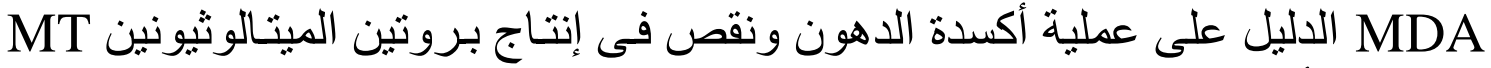

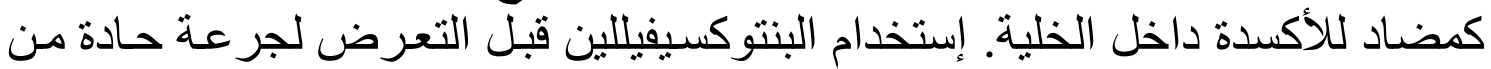

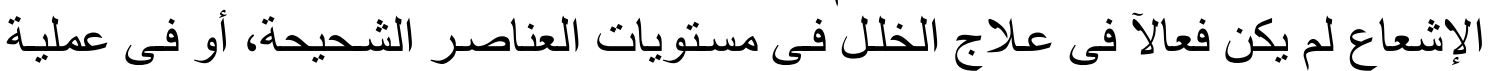

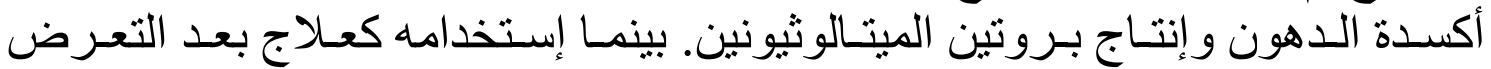

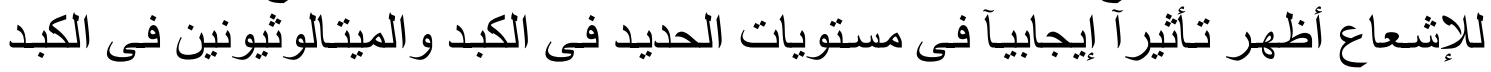

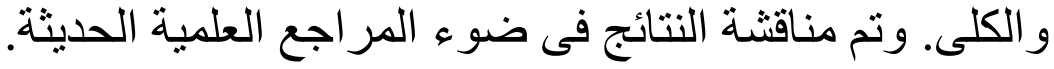

